\title{
The moral geographies of public sector job relocation: discourses of compensation and competence in the Swedish news press
}

\section{Angelika Sjöstedt Landén, Karin Ljuslinder \& Anna Sofia Lundgren}

To cite this article: Angelika Sjöstedt Landén, Karin Ljuslinder \& Anna Sofia Lundgren (2017) The moral geographies of public sector job relocation: discourses of compensation and competence in the Swedish news press, Social \& Cultural Geography, 18:5, 623-644, DOI: 10.1080/14649365.2016.1210668

To link to this article: https://doi.org/10.1080/14649365.2016.1210668

Published online: 03 Aug 2016.

Submit your article to this journal $\sqsubset$

Џll Article views: 239

à

View related articles $\sqsubset$

View Crossmark data

Citing articles: 3 View citing articles $匚$ 


\title{
The moral geographies of public sector job relocation: discourses of compensation and competence in the Swedish news press
}

\author{
Angelika Sjöstedt Landén, Karin Ljuslinder and Anna Sofia Lundgren \\ Department for Culture and Media Studies, Umeå University, Umeå, Sweden
}

\begin{abstract}
Previous research has pointed to the fact that ideological images of geographies are bound up with the ongoing struggle for economic and social resources, and that moral values and emotions are central in rendering such images intelligible and accepted. To explore this further, we critically engage with the ways in which moral values and emotions contribute to the (re)production of centres and peripheries in the Swedish news press reports of public-sector job relocations. We deploy the discourse theoretical notion of ideological fantasy to critically explain the forces that make particular moral and emotional judgements comprehensible. We identify two discourses in the news press material - one about competence and one about compensation - built up by morally and emotionally charged articulations. We argue that ideological fantasies worked as driving forces both in this moral and emotional news debate and also in the ongoing constitution of geographies.
\end{abstract}

\section{Géographies morales de la délocalisation de l'emploi dans le secteur public: discours de compensation et de compétence dans la presse suédoise}

\section{RÉSUMÉ}

Les recherches ont démontré que les images idéologiques des géographies sont liées à la lutte actuelle pour les ressources économiques et sociales et que les valeurs morales et les émotions sont essentielles pour rendre de telles images intelligibles et acceptées. Pour une exploration approfondie, nous faisons une analyse critique des manières dont les valeurs morales et les émotions contribuent à la (re)production de centres et de périphéries dans les reportages de la presse suédoise sur les délocalisations des emplois du secteur public. Nous déployons la notion de discours théorique du rêve idéologique pour expliquer de façon critique les forces qui rendent certains jugements moraux et émotionnels compréhensibles. Nous identifions deux discours dans les documents de presse - un sur la compétence et un sur la compensation - accumulés à travers des articulations empreintes de valeurs morales et d'émotions. Nous arguons que les rêves idéologiques ont agi en tant que moteurs puissants à la fois dans le débat moral et émotionnel dans l'actualité et dans la constitution en cours des géographies.

\section{ARTICLE HISTORY}

Received 28 February 2014 Accepted 11 June 2016

\section{KEYWORDS}

Public-sector relocation; moral; emotion; discourse; centre and periphery

\section{MOTS CLÉS}

délocalisation du secteur public; valeur morale; émotion; discours; centre et périphérie

\section{PALABRAS CLAVE}

reubicación del sector público; moral; emoción; discurso; centro y periferia 


\section{Las geografías morales de reubicación laboral del sector público: discursos de compensación y competencia en la prensa sueca}

\section{RESUMEN}

Investigaciones anteriores han señalado el hecho de que las imágenes ideológicas de las geografías están ligadas a la lucha permanente por los recursos económicos y sociales, y que los valores morales y las emociones son fundamentales en hacer que este tipo de imágenes sean inteligibles y aceptadas. Para explorar esto más a fondo, nos involucramos críticamente con las formas en que los valores morales y las emociones contribuyen a la (re) producción de centros y periferias en los informes periodísticos suecos sobre la reubicación de puestos de trabajo del sector público. Se utiliza la noción teórica del discurso de la fantasía ideológica para explicar críticamente las fuerzas que hacen comprensibles determinados juicios morales y emocionales. Se identifican dos discursos en la prensa - uno acerca de la competencia y uno sobre la compensación - construidos por articulaciones con carga moral y emocional. Se argumenta que las fantasías ideológicas fueron la fuerza impulsora tanto en este debate de noticias moral y emocional y también en la permanente constitución de las geografías.

\section{Introduction and background}

Public sector job relocation spans a range of central public administration and policy-making discourse in terms of geographically distributing power and resources in centrally governed countries (see e.g. Marshall, 2007; Sjöstedt Landén, 2012a; Trondal, 2011). Paradoxically, as a policy measure, relocations generally take the centre and its proposed hinterlands for granted (Marshall, Hodgson, \& Bradley, 2005; Trondal, 2011; Winckler, 1990) and presume (urban) centrality to be the normal state of affairs to begin with (Sjöstedt Landén, 2012a). With its history of strong central governance, Sweden is known for its regional policy during the long period of Social Democrat Government (Brandt, 2010; Hansen, 1998). As Isaksson (1989) has pointed out, relocations have certainly been a part of that governing commitment.

Historically, the largest relocation in Sweden took place in the 1970s, when around 10,000 jobs were moved from Stockholm (Berger, 1995; Brandt, 2010; Statskontoret, 1989). Since the 1990s, the political discourse of state decentralisation has moved towards a neoliberal stance, and is today more focused on regions' abilities to create their own growth. This has also affected the role of public sector relocations and the geographical organisation of state institutions (Brandt, 2010; Trondal, 2011). Although the Swedish Government now pays more attention to promoting regional growth (Hudson \& Rönnblom, 2007), relocations are still in its repertoire of policy measures. With this background of politics in mind, we believe that the shifts and nuances of public discourse are interesting because of how they are articulated using values and emotions in spatial contexts. The uneven distribution of population, resources and power has also resulted in non-urban parts of the country becoming subject to processes of 'internal othering' by the media (Eriksson, 2008; Jansson, 2003) and, consequently, to the production of centres and peripheries within the nation. In Sweden, as in many other parts of the world, the less urbanised areas have been represented as supposedly less developed, less modern and more peripheral than the perceived (urban) centres 
(Eriksson, 2010b; Halfacree, 2006; Woods, 2006). Such representations have also been found to impact on the ways in which people describe and relate to their past, present and future (Pred, 2000; Sjöstedt Landén, 2012b), influencing politics as well as policy (Hansen, 1998; Lefebvre, 2003). The processes of constructing centres and peripheries, which are deeply embedded in social relations, further tend to become inextricably linked with both values and emotions (Cresswell, 2005; Massey, 2005) and, as we shall see, proved to be central to the way relocations were debated. In that respect, our study aims to understand'antagonistic processes of valuation' (Harvey, 1996, p. 11).

In this article, we focus especially on the public news press debate before and during the most current wave of Swedish public sector job relocations in 2004-2008. Following the shutdown of four army regiments in 2004, the government decided to relocate public agencies (or parts thereof) from the capital of Stockholm to the same towns and regional centres that had lost a regiment. The decision to relocate government agencies to the towns affected by the closing of regiments caused controversy and was much debated in the national and the local news press. At first glance, the debate was about the pressing question of job opportunities, but a closer reading proves to have a bearing on deep-rooted, morally and emotionally charged imaginings of place and place-related identities. Regardless of how practical and supposedly 'rational' and 'logical' the question of relocations of government agencies appeared to be at first, morally invested feelings, values and opinions were at work, persuading for or against the agencies' relocation from Stockholm to other parts of the country. In order to make a case for the importance of a sensitivity to moral and emotional geographies and how they inform political antagonisms, we critically engage with the ways in which such moral and emotional geographies acted in the news press representations to consolidate, but also to challenge, accepted power relations that underpin Sweden's regional policy practice in public sector job relocations. The central questions concern how moral values and emotions are articulated in the news press reports of the relocations of government agencies and what that does in terms of installing, reproducing and contesting spatial power relations. We aim to explore further how moral values and emotions contribute to the (re) production of space and place and thereby contribute to current debates over the concepts of affect and emotion within human geography (see e.g. Curti, Aitken, Bosco, \& Dixon Goerisch, 2011; Dawney, 2011; Pile, 2010). Rather than merely describing these articulations, we deploy the discourse theoretical notion of ideological fantasy. We use this concept to understand and critically explain the workings of the persistent identifications of urban and rural, centre and periphery, that form the taken-for-granted basis of debate where the politics of space are at stake.

\section{Theoretical points of departure and analytical strategies}

Our theoretical perspective acknowledges that ideological images of geographies are bound up with ongoing struggles for economic and social resources. Moral values and emotions are as central when rendering such images intelligible and accepted as they are when challenging them (Cresswell, 2005). We draw on the fields of moral and emotional geography for insights which also sits well with the post-structural, theoretical framework of political discourse theory (PDT). 


\section{Discourse, articulation and fantasy}

The concept of discourse is central to our study of news press representations. Discourses 'endeavour to impose order and necessity on a field of meaning' (Howarth, 2000, p. 103) whereby a discourse captures the ways that a certain phenomenon is understood in a given time and place. Nonetheless, such privileged fixations are always preliminary since discourses are simultaneously contingent, performative and constitutive (Laclau \& Mouffe, 1985). When we studied the news press debate, we found that the concepts of 'compensation' and 'competence' worked as privileged elements that tried to 'arrest the flow of differences, to construct a centre' (Laclau \& Mouffe, 1985, p. 112) in the argumentations about public sector job relocations. In our analysis, we argue that these central concepts form two different discourses that could be observed as patterns in the material, although they were not completely coherent in the sense that their meanings were consistently and permanently fixed. Instead, when we describe their characteristics, we have tried to point out the ways they are typically constructed in the news press material. It is however important to note that describing the typical characteristics of a discourse does not exhaust its analytical potential. We also found what we consider to be counter-discourses constructed in opposition to dominant ways of describing the relocations. Following Foucault's (1980, p. 142) notion that 'there are no relations of power without resistances', and that such resistances 'are formed right at the point where relations of power are exercised', we hold counter-discourses to be inextricably related to more dominant discourses and revealing of the contingency of discourse. Counterdiscourses question the legitimacy of claims made by the 'dominant' discourse, thus disclosing the limits of that discourse. The emotional investment in the imagination of alternatives that is characteristic of most counter-discourses (Terdiman, 1985, p. 87) proved decisive in our efforts to explain what made the studied moral and emotional geographies attractive - what made them 'tick' (Glynos \& Howarth, 2007).

In order to pinpoint how a discourse is constructed, we rely on the notion of articulation as conceptualised by Laclau and Mouffe (1985, p. 105), who state that articulations establish relations among elements 'such that their identity is modified as a result of the articulatory practice'. When we describe the discourses in the material and the articulations that constitute them, it is articulations between elements that we imply. Thus, an element can be a certain kind of emotional wording, a certain kind of position or positioning or a certain way of referring to relocations. Laclau in particular has been criticised for not taking situatedness and spatiality into account in the theory of articulatory practices (Massey, 2005). This is also a reason why we found the combination of discourse theory and theories of moral and emotional geography to be particularly interesting to explore. Moreover, recent developments within PDT have turned to the concept of ideological fantasy as employed by, amongst others, Glynos and Howarth (2007), Glynos (2001, 2008, 2009) and Žižek (1993) as a way of emphasising the affective and emotional aspects of discourse. Fantasy in this Lacanian sense should not be mistaken for false representations or distorted consciousness; it is rather a shared view and a futurised desire to rely on in order to explain the world in general and, more specifically, to make any contingent situation comprehensible. Fantasies are thought to cover over or conceal contingency by providing explanations of why the enjoyment brought on by the fulfilment of the fantasy is always missing and what would be needed in order to reach such a sense of fulfilment. In the present case, we will show how emotional 
and moral positionings were constructed within the discourses about compensation and competence and how these positionings may have given rise to such enjoyment.

Bringing this Lacanian perspective (Glynos, 2001) to bear on news press material includes posing questions about how geographical fantasies were invoked for making particular moral and emotional judgements comprehensible. Fantasy could thereby be said to do something with the news press debate and its morally and emotionally charged representations; it worked as an organising force. Glynos (2009) argues that bringing the fantasmatic aspects more clearly into PDT highlights the affective and emotional as a core part of the theoretical framework. In order to explore the invocation of what moral values and emotions do when articulated in terms of geographical locations and identities, we furthermore want to connect these discourse theoretical developments to the fields of emotional and moral geographies.

\section{Emotional and moral geographies}

During the last decades, studies in geography have highlighted how notions of place and space are closely related to both emotions (Davidson, Bondi, \& Smith, 2007) and morals (Lee $\&$ Smith, 2004); that place and space are co-constructed with feelings as well as with notions of right and wrong. We consider emotions to be culturally productive in the sense that they are contextual as well as performative: contextual in the sense that what counts as emotion or moral is not a universal truth; performative in the sense that emotions and morals do something in constituting a phenomenon (see Ahmed, 2004). They may, for example, act as cultural focal points; drive mobilisation; offer identifications or reinforce a sense of alienation (Ahmed, 2004; Brown \& Pickerill, 2009; Davis, Crothers, Grant, Young, \& Smith, 2012). Importantly, and in accordance with Horton and Kraftl (2009), we wish to avoid the kind of 'separatism' that keeps work on emotion separate from social science research that is more focused on policy (see also Anderson \& Smith, 2001), and instead study their juxtaposition in order to be able to offer a critical explanation of the significance and persistence of spatial power orders in policy debates.

We have read the news press material for how emotion was articulated in the argumentations, both as references to emotions and as emotional expressions, i.e. we have included explicit literal references to feelings (such as 'anger','sadness' or 'frustration') but also expressions that were emotional in character (in the sense that they expressed opinions in an emotive manner, for example, by the use of exclamation marks or strong words). It is important to point out that these references to emotions and emotional expressions are viewed as signs trying to fix the meaning of public sector job relocation.

Perhaps because of the antagonistic nature of the material, which to a large extent consisted of debate articles, expressions of emotions were often articulated with notions of morality. Relocations were alternately represented as good or bad, right or wrong, proper or improper. To account for this, moral geography is a useful concept for pinpointing how geographical categories become laden with moral values (Cresswell, 2005; Massey, 2005). Lee and Smith (2004) argue that the prime concern of moral geography is the way in which morality is said to bind people to places and to identities related to place, and to that end they scrutinise the effects of the common notion that 'certain people, things and practices belong in certain spaces, places and landscapes and not in others' (Cresswell, 2005, p. 128). It has also been highlighted that moral values are played out differently in different places 
(Valentine, 2013).The concept of moral geography helps to analyse 'the taken-for-granted relationship between the geographical ordering of the world and ideas about what is good, right and true' (Cresswell, 2005, p. 132), and so highlights important power structures. By these references to what was articulated as 'right' or 'wrong', 'good' or 'bad', 'proper' or 'improper', geography, and identifications related to space and place were negotiated and (re)produced (see also Boltanski \& Thévenot, 1999, 2006). Moreover, we align with Massey's (2005) claim that different ways of conceptualising 'the spatial' provide bases for the politicisation of space. This links back to our interest in analysing the power relations intertwined in the articulations of public sector job relocations.

\section{Source material}

Previous studies of Swedish relocations have noted how people involved in public sector relocation work reacted strongly to how the process was represented in and by the media (Sjöstedt Landén, 2012a). Despite the impact of social media on how individuals consume and share news (Lee \& Ma, 2012), the news press is still counted as one of the most important sources of information (Carlsson, 2014), and print news press articles are generally easily accessed and spread on the Internet. This makes the news press an important mediator by and through which meaning is constituted and spread. This is our motivation for studying news press and we are especially interested in the spatialised power relations that media representations carry. We depart from the assumption that geographies are constantly mediatised (Halfacree, 1993; Jarosz \& Lawson, 2002; Woods, 2011) and that this is essential given the constantly ongoing symbolic reproduction of cultural values that takes place in the media (Hall, 1997; Ljuslinder, 2002). This does not mean that geographies are determined by such mediatisation, but mediated representations often constitute and support dominant narratives that tend to 'colonise' people's life worlds (Lundgren, 2011; Massey, 2005; Vallström, 2014) and affect how public policy is formed and argued for or against (Marshall et al., 2005).

With this in mind, we decided to approach the emotional and moral geographies evoked by the relocations through the print press. The material consists of editorials and reports in the Swedish daily press from 1 September 2004 to 31 December 2008: these were identified as key dates for the start and end of the latest wave of relocations. News articles were collected from the media monitoring tool Retriever. The studied news articles were published in Swedish and translated by the authors. A first selection of the material was made by selecting national, regional and local papers in order to avoid branch magazines and other specialised news press. For this defined material, the search-terms 're' OR 'out' AND 'location' (sv."'om" OR "ut" AND "lokalisering"') were then used. The search yielded 389 items in 28 daily newspapers, including newspapers produced in the different geographical areas affected by the relocations. The time span used for the search was chosen to capture the media debates about the suggested closure of the four army regiments in the run-up to the government's decision in December 2004, the subsequent decisions to relocate government agencies, up to the finalising of the last relocation in 2008.

The 389 items comprised a variety of genres - editorials, news reports, op-eds and letters to the editor - which were read and analysed with regard to how they articulated the relocations they dealt with. We specifically noted how notions of place were employed, and we soon realised the common emphasis on moral values and the use of emotion. Of course, 
the focus on news press material may not seem to be the most obvious way to engage in a study of expressions of moral values and emotion. Despite this, however, 'journalistic genres remain infused by emotion' (Wahl-Jorgensen, 2013, p. 130). The news press's way of fixing discourse 'in ink' together with its capacity to reach large audiences supported our use of this specific material. The material was then coded for articulations between relocation and geography and moral and emotional comments, statements and declarations.

In the following, we give a brief account of the most recent wave of Swedish relocations. We then describe the features of the discourses of compensation and competence, respectively: their main characteristics and the way they were built up through morally and emotionally charged articulations. We also give examples of how these efforts were challenged by counter-discourses and efforts to affix a different meaning. We conclude by discussing the emotional and moral geographies of the studied relocation fantasies.

\section{Exploring relocation discourses}

The most recent wave of Swedish public sector relocations began in December 2004 when the Swedish Government approved a proposition to disband the army regiments of four Swedish regions that were represented by the towns of Arvidsjaur, Karlstad/Kristinehamn, Östersund and Visby on the island of Gotland (see Figure 1). Each town is a population centre in its region and most of them have universities or satellite university campuses located in the town. In most cases, these towns are surrounded by large areas with quite sparse and dispersed populations. In total, 2,500 civil and military jobs were to be moved from the four regions. This was seen as a big blow for each of the regions since all four had relatively vulnerable labour markets, and the decision provoked strong local protests. ${ }^{1}$

Shortly thereafter, a Localisation Commission was appointed to identify potential government agencies that could be relocated from Stockholm to the local centres of the four regions affected (Localisation Commission N 2004:15). The Commission's investigation indicated that there were indeed agencies or parts of agencies that could be relocated from Stockholm, and reports to that effect started to appear in the press for the first time in late 2004 (e.g. Kihlström, 2004). These were all jobs requiring highly qualified personnel with undergraduate or postgraduate degrees. When the decision to relocate government authorities was later made official, it stirred up a heated debate in the press that ran from the announcement of the Commission's findings to the final governmental decision that the proposed relocations should take place. The decision to act on the Localisation Commission's proposal was then taken by the government in June 2005 (Riksrevisionen, 2009).

\section{A discourse about compensation}

Claims for compensation for the close-down of the regiments were evident throughout the material. Such claims contributed to the constitution of a discourse about compensation that was primarily employed by writers who identified with 'the regions'. It was often rather unclear what was going to be compensated for: the jobs for the individual employees affected by the closures or general job opportunities to compensate for the dent in the regions' local taxbase. Regardless of which, the claims were repeatedly justified, and articulated with morally laden elements such as references to justice, fairness and responsibility. 


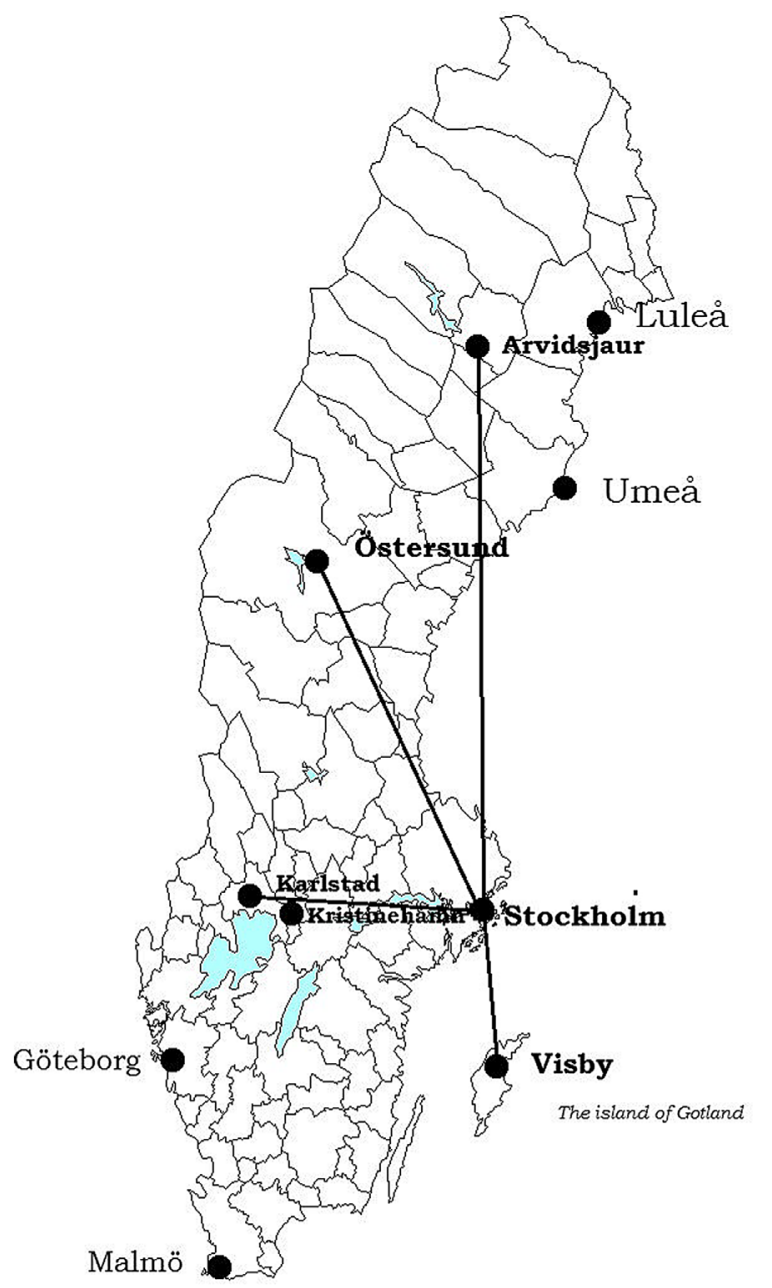

Figure 1. Lines mark the nodes for relocation of agencies from Stockholm.

Some examples of such formulations were: (1) 'There is every reason to demand fair treatment ... and the relocation of agencies that would provide the most jobs if the regiment goes' (Persson, 2004), (2) 'the state has a responsibility to the county if the garrison in Östersund disappears' (Persson, 2004), (3)'we have the right to demand a substantial bailout from the state' (Östersunds Posten 21 September 2004). In example 1 quoted above, the act of relocating agencies was articulated in terms of 'fair treatment' as a way to justify the demand for relocation of agencies. It was expected that the government or state would shoulder responsibility for the situation, both the closure of the regiments and the mass unemployment that was the feared consequence. It was illustrated in the articles that the claiming of 'rights' united a range of people who expressed the shared feeling of being let down by the closures - people who were themselves at risk of losing their jobs, including local and regional politicians acting as representatives of the affected areas. Expressions of having been let down thus worked as important elements in the discourse about compensation. 
In claiming rights, the representations drew not only on a general sense of 'justice', but also on historical events, as in the following, in which a previous injustice, never compensated for, is used to justify present claims.

During the 1990s, Arvidsjaur lost 500 government jobs at The Swedish National Rail Administration, the police, and the tax authorities. 'We did not demand any replacement jobs then, so now we want 720 new jobs.' (Hennel, 2004)

By demanding fair treatment and compensation for what was being taken away, they urged the government to take what was referred to as proper and responsible measures. These demands were in line with the discourse of Swedish welfare society in the aftermath of the Second World War when the relocation of public agencies was one of the common means by which notions of justice and fairness were practised in regional politics (see also Isaksson, 1989).

Inherent to such compensation claims was a distinction between centre and periphery, where the geographical location of the capital city of Stockholm unquestionably embodied the centre. ${ }^{2}$ The notion of a spatially specific centre of resources and power positioned in Stockholm was represented in such a way that it rendered Stockholm synonymous with the central government. As such, it also became represented as a subject in its own right in the news press. 'Stockholm' could thus be described as 'taking away' things that belonged to the regions in question, and claims for justice were therefore sometimes directed not towards the government that had decided on the question, but towards the geographical area of Stockholm, or even its inhabitants, the 'Stockholmers'. This way of positioning the area of Stockholm as a subject, a naturalised centre and agent of power, was also visible in the rhetoric and the choice of words more generally. A commonly used Swedish synonym for the word relocation (sv.omlokalisering) is out-location (sv.utlokalisering). The use of the term 'out-location' underscored how the relocated agencies were not only moving between supposedly neutral and equal geographical areas, but were moving away from the centre and out into a perceived periphery. The choice of this word thus also construed the supposed centre as something original and given: the place where the relocated agencies really and originally belonged (Sjöstedt Landén, 2012a, p. 3).

Across the board, the relocations were referred to in the press in a language that indicated the emotional significance they were expected to have for people. This was the case regardless of whether the press reports represented people living outside Stockholm (who were expected to lose their jobs due to regiment closures, and therefore demanded compensation), or people living in Stockholm (who needed to re-evaluate their work situation due to the relocation of their workplaces). Particular places as well as individual employees were described as being 'hit by the planned changes', which in turn were understood to put'a lot of pressure on the individuals concerned' as they were forced to'decide what is best: a move or a new job' (Bjurnemark, 2005).

One emotional state that was repeatedly expressed in the news press reports was the feeling of betrayal and of having been 'let down':

I feel let down by the Department of Defence. I don't think they've done a decent job, said Per Lavander, mayor of Arvidsjaur, which is losing K4, the Norrland Dragoon Regiment. (Hennel, 2004)

It is in this reported sense of betrayal that the power relations between centre (the Capital) and peripheries (the regions) are made visible, and the claims for compensation and fairness are shown to be about more than economy and jobs. It is a case in point, given that these 
feelings demonstrate how power relations between centre and periphery were also about trust and reliance. The terminology used visualised the centrality and power ascribed to what may be referred to as 'the responsible state', and strongly connected with Stockholm as a geographical area. While effectively covering over the contingency of the demands raised on the basis of it, the fantasy of the responsible state made it possible to feel wronged and aggrieved, but also, and more importantly, to identifyas wronged and aggrieved. However, Ahmed (2004, pp. 193-196) argues (with reference to Berlant, 2000) that injustice cannot be reduced to feeling bad, but that it could be the effect of unjust treatment and thereby emotions involve investments in social norms. Viewed in this way, the concept of fantasy may explain something about the way that the discourse about compensation bringing together elements such as 'a strong state' and expressions of having been let down by this state - was representing people in the region as morally entitled to make certain claims on the government in Stockholm. However, the discourse about compensation was also critiqued by a counter-discourse that argued in favour of local enterprise rather than relocations of state agencies as a way to be free from subordination to the 'centre'.

\section{Countering the discourse about compensation}

One recurring critique of the discourse about compensation urged regions not to enter into submissive power relations.

Stop begging for government relocations, examples of successful ones are very few [...] Do not ask the state for new public jobs in the county, have the courage to say no to something that in any case hardly seems to be reliable! (Pripp, 2004)

By using words such as 'begging' (for what was otherwise called 'demanding fair treatment') or 'courage' to free themselves from a dependence (that was otherwise thought of as a'right' and a 'responsibility' of the state), these representations worked as elements of a counterdiscourse that destabilised and re-signified the discourse about compensation. The statements imply that using the relocation of public sector authorities as compensation was a way of handling the situation in which the recipients would become positioned as subordinate, submissive and indebted to the 'giver'. According to the logic of this counter-discourse, relocations were conceptualised as constituting performative acts of power, whereby the nation produces its subjects as well as itself. However, fair and just the 'gifts' and 'promises' of relocation appeared to be at first, they were further destabilised. From the position of the recipient areas, the aversion to entering into the relations imposed by the relocations was also emphasised in remarks about the doubts whether such promises would ever be fulfilled. This suspicion in turn enabled the claim that receiving compensatory jobs from the government would hold back the local business sector, and that this would undermine people's sense of their own responsibility for the survival of the region. The antidote to the loss of governmental work was instead said to promote entrepreneurship and private enterprise - duly associating public agencies with insecurity and short-termism and smaller enterprises with productiveness and job opportunities:

The public sector is not a reliable, long-term basis for growth. History shows that in the end it is our small businesses that have best provided the bulk of the productive workforce with a livelihood, not the public sector. (Pripp, 2004)

The standpoint of seeing the public sector as unreliable seemed to join forces with the critique that saw public sector relocation as positioning the receiving areas as subordinate: 
The idea of replacement jobs if the public sector disappears from a community or start-ups to strengthen a region thus seems like small comfort [...] After all, even the private sector creates highly skilled jobs. [...] You just have to shake off the idea that the rescue has to come from Stockholm. (Krantz, 2008)

I think it would be wise if in future we did not demand these sorts of replacement jobs in Gotland. [...] Hopefully this might mean a larger and more dynamic business sector on Gotland in future. God helps those who help themselves. (Linder, 2009)

Here too dependence on the state is targeted, but for reasons described in terms of promoting local enterprise. The hegemonic position of the Swedish Model in regional politics has been increasingly and generally challenged (Brandt, 2010), and the counter-discourse made common cause with the continuous questionings about the extent to which state responsibility could be comprehended as a 'rights issue'.

There is reason to believe that Fraser (2009, p. 72 ) is right in saying that 'the recent resurgence of free-market thinking has put proponents of egalitarian redistribution on the defensive', although these are the most theorised claims for social justice that also form a strong discourse in the relocation debate. The presence of a counter-discourse that destabilised the compensation discourse certainly indicates that the change in regional politics in favour of an increased emphasis on decentralised and neo-liberal policy (Eriksson, 2010b; Hudson \& Rönnblom, 2007) supports another kind of relation to the state. The challenge of the counter-discourse also sheds light on how the presence of a neoliberal ideology partly came to structure the emotional space in which counter-discourses ascribed defensiveness to the claims for compensation, and, simultaneously, to the areas from which these claims were made.

Even if compensation constituted a quite strong discourse, equally the chosen path of government, it became laden with notions of (peripheral areas') dependency on the central government. The efforts to counter the discourse about compensation emphasised the need to alter the way of acting within the region and were laden with a fantasy of good prospects. This fantasy was structured by a logic that promised a bright future if only the way of acting within the region is changed. But, especially in the regions in northern Sweden, market solutions are challenging because of the long distances between people and the small populations within each region. It is thus difficult to achieve what is asked for. Furthermore, the argument does not change the unequal relationship between 'Stockholm' and 'the regions'. As suggested by Berlant (2002, p. 75; quoted in Ahmed, 2004, p. 196), it is a 'stupid form of optimism' because promises of good prospects if certain things are accomplished often sustain the logic of centre and periphery inherent in the way the state is already organised.

Demands for compensation were however not the only line taken in the press reports about the public sector relocations. When the news broke about which agencies were slated for relocation, 'competence' was repeatedly debated and came to constitute an important feature of the news press discourse.

\section{The discourse about competence}

It was at times vividly argued that compensatory politics should not be the overarching determinant for going through with relocations. Instead, decision-makers should look to the competence needed for keeping high quality in the state apparatus. The decisions for or 
against relocation should therefore build on judgements of how best possible competence should be provided within the government agencies. This resulted in different ways of arguing for competence: regions started to make a case for a regional profile of competence as a reason to have a state agency relocated there. This was the case also in regions where the right to 'compensation' previously constituted the strongest argument. Nevertheless, in these cases, the discourses about competence and compensation could also be combined in favour of relocating agencies from Stockholm to other towns. The agencies that were already located in Stockholm used competence as their most important discourse for resisting relocation by emphasising the expertise they had and that this was particular to the location.

In the scramble to attract the relocated agencies, competencies as well as geographically associated advantages were put forward and agencies were said to be particularly suitable for locating in certain places. The first quote below shows how the profile of a region was constructed as 'competence', while the second quote simply states that 'specialised expertise ... is to be found in Stockholm':

In that case, the Environmental Protection Agency feels absolutely right. We have Jämtland's tourism profile based on its unspoilt nature, and the university has several research projects related to the Environmental Protection Agency's areas of interest. For example its Ecotechnology course. [...] Östersund Rural Development Agency and ITPS (Swedish Institute for Economic and Regional Growth) are already here, so something based on community development feels like a natural choice because we are able to offer the right expertise. ('Vilka är de viktigaste', 2004)

Norgren referred to the fact that his agency works a great deal with both the Stockholm City Court and the Swedish Market Court in Stockholm. Moreover, all the necessary specialised expertise in economics and law is to be found in Stockholm. ('Verkschef vill', 2004)

These are examples of how certain sets of competencies were affiliated with geographical specificities. In the case of the regions such as Jämtland and Gotland, competencies were strongly connected with stereotypical characteristics of each region. Stockholm was articulated in terms of excellence and expertise, and, crucially, a geographical proximity to expertise. The linkages between different locations and certain kinds of competence implied a spatial division of labour that in turn was utilised to argue for or against agencies moving. Within the discourse about competence, there seemed to be a fight for how to fill the concept of 'competence' with meaning in the relocation debate. At the same time as the argument for a specific kind of unique regional competence was common in the material, areas outside Stockholm were repeatedly said to lack competence in terms of educated staff.

The Swedish National Archive of Recorded Sound and Moving Images (SLBA), with 65 employees in Stockholm, is Sweden's national archive of recorded sound and moving images. For reasons of competence, they say that it cannot move from Stockholm. ('Verken vill', 2004)

Lack of competence was an element that was also articulated in relation to an unwanted dependency on the state, an articulation that could easily be paired with the argument that regions should be 'independent' as in the countering of the discourse about compensation:

In smaller towns, far from higher education institutions, it may be difficult to find the right competence, and, moreover, it is desirable to get away from dependence on the public sector. (Andersson, 2005)

Specialist competence was also seen as naturally rooted in the capital and therefore particularly difficult to 'find' outside it. Eriksson (2010a) has described the notion of Stockholm(ers) as more competent as an expression of internal orientalism that subordinates people and places within the national imaginary. The articulations of competence are 
revealing of how particular directions of internal migration and movements of qualified workforce were privileged. ${ }^{3}$ In the media material, the specialist competence located in Stockholm was seen as exceptionally difficult to move.

It thus seems that public authorities are not well suited to moving. The specialist skills required are difficult to replace and will take time to rebuild. (Krantz, 2008)

While regional areas are otherwise often represented as stable and stagnant, the discourse about competence similarly positioned the competent Stockholmers as immobile and could be seen as countering the otherwise strong discourse that usually advocates a flexible and highly mobile workforce (see e.g. Zimmerman, 2009). All in all, 'Stockholm' was articulated as competent per se and the origin of expertise. Just as Stockholm was reified as a subject that was expected to compensate sparsely populated areas when jobs had been taken away, it was also reified as a competent subject. However, Stockholm was not the only place held up as more competent in relation to the supposed incompetence of other regions of Sweden. Rather, the scale and suitability of that competence were continuously negotiated. Hierarchical relations were also constructed between the smaller towns. For example, in the case of Östersund and Karlstad, Karlstad was preferred over Östersund due to its geographical proximity to Stockholm. The division of labour articulated in the quotes built on the idea that different places were connected by status and hierarchical relations. One example of this was when the relocation (here translated literally as out-location) to a place outside Stockholm was articulated as a sign of degradation and the assignment of lower status:

It is not possible to free oneself from the suspicion that some of the out-located authorities are the ones the government cares less about, but which nonetheless cost taxpayers big money. Perhaps the list of ones to relocate could just as well be used as the basis for a discussion of which authorities could be phased out completely? ('Mindre värda', 2005)

This was even spelled out on occasion: because of the loss of competence and distancing from loci of importance, moving an agency from Stockholm could be synonymous with closing it down.

The head of the Swedish Institute for Transport and Communications Analysis (SIKA) claims that a relocation to Östersund would be the same as a closure. (Larsson,2005)

The employees of the agencies in Stockholm were frequently described as feeling degraded or hurt saying, for example, that 'employees feel aggrieved when politicians do not value their competence' (Brors, 2005). This illustrates the ways in which expressions of emotion were elements that, in the discourse about competence became intertwined with the arguments that it was (morally) wrong or right to uproot the competence that already existed in Stockholm. In the quote below from the most influential daily business paper in the country, a distraught journalist, excelling in exclamation marks, is referring to the state as 'a cold employer' when reporting on the public inquiry into possible relocations:

There is talk of civil servants 'who choose not to move' when out-located to other places. As if they had a choice! In most cases, naturally, it's because they can't move for family reasons. It's a bit cynical to present it as staff choosing to give up their jobs - when in reality it's the state that's snatched their jobs away from them! ('Statligt mord', 2005)

The choice of the word 'out-location' is here symptomatic of the Stockholm perspective of the journalist. The article critiques the morality of the discourse about compensation for only thinking of people outside of Stockholm and not of the Stockholmers. In this sense, the 
quote destabilises the notion of morality and fairness enforced by the discourse about compensation, but enforces the dichotomisation brought on by it.

The two identities thus evoked by the discourse about competence were (incompetent) employees outside Stockholm and (competent) employees in Stockholm. Sometimes, however, 'the nation' surfaced as an empty signifier (Laclau, 2005), claiming to comprise all identities regardless of where they were positioned geographically. What happened when the nation was invoked as stakeholder was that yet another fantasy surfaced in the news press representations; a horrific fantasy of national loss if the relocations were carried out. According to this fantasy, the one with something to lose was not Stockholm, nor Stockholmers, nor different geographical areas around Sweden - it was Sweden itself and Swedish citizens. The idea that something would be lost if the move went ahead was recurrently described as a threat to (the ideological idea of) the nation. Although the underpinnings of this fantasy of impending loss and brain drain were sometimes refuted (as will be clear), it seemed to have a firm grip on the arguments against relocation. Sometimes this was achieved simply by formulating the object of discussion not as separate agencies, but as 'key state services':

[The director of the Swedish Consumer Agency] fears 'a remarkable loss of competence' and is concerned that only a quarter of the staff will move to Karlstad. [...] Key state services risk losing skills and capabilities. (Bjurnemark, 2005)

The act of relocating public sector agencies from Stockholm to other parts of the country was also constructed as a horrific threat to national interests articulated as 'growth' in general, as 'consumer rights' or, as in the quote below, as 'Swedish heritage'.

And the reason for that, after all, is that there are public authorities and then there are public authorities. Not all of them have bureaucrats. Some have specialists who cannot be replaced any old how. At the National Heritage Board, there are basically only specialists. If they go, then the possibility of the agency fulfilling its mission, which is to protect Swedish heritage, goes with them. ('Rädda svensk', 2007)

Hence the fantasy of national loss if relocations were carried out managed to invoke the nation and its citizens as the stakeholders in relocation, rather than specifically affected geographical areas or civil servants. This way of universalising, or at least casting the net wider for the problems with relocation, prompted readers to assume the position of 'the responsible state' (and position themselves as its 'citizens') - only responsibility was now rather symbolised as 'not to relocate' than 'to relocate'. What seemed reasonable and fair in the discourse about compensation (the state giving back what had been taken away) was effectively undermined, because readers potentially identifying with positions deemed peripheral, were also, as it were, Swedes.

This strategy of appealing to the readers as citizens of the nation rather than as inhabitants of a region or a city (or as individuals or employees) may be seen as a hegemonic intervention that reconstituted unambiguity (Laclau, 1993) in the sense that it - temporarily - naturalised the particular articulation of relocation as a threat to national competence (see Torfing, 1999).Three processes were central in this intervention: the reliance on the discourse about competence and its dominant articulation of competence as residing in Stockholm, the highlighting of the agencies chosen for relocation as belonging to the nation and the installation of 'the nation' as an empty signifier in relation to which all readers could potentially identify themselves as 'Swedes'. As a consequence, the practice of relocation was successfully equated 
with a general threat where the sovereignty of the nation state was threatened by the degradation of its (competent) institutions.

Behind the perceived threats of relocation was the fantasy that relocations of agencies would be very costly and that the agencies would become less efficient. The arguments of competence thus invoked economic rationalisations, for example, when the cost of employees commuting from Stockholm to Gotland was put forward as an argument against relocation:

The proposal to move hundreds of people will lead to increases in travel costs for staff, because few are willing to settle on Gotland. I do not think that the investigators have any real overall sense of the organisation. (af Kleen, 2005)

Here, commuting costs constitute a comprehensible argument for two key reasons. These are first, because of the implicit assumption that there is no competence already on Gotland, hence the need to transport employees from Stockholm, and, second, because of the assumption that no one would want to move to live on the island of Gotland (thus not having to commute at all). By arguing that relocation increases costs, it could also be seen as immoral to move the agencies because it would result in an illegitimate waste of taxpayers money.

The efforts to hegemonise the debate, however partial or temporary the effects, rested on an effective chain of equivalence that likened the position of 'Stockholm' with the more inclusive position of 'Sweden'. This equivalence of elements effectively reinforced the position of Stockholm as the centre by definition, and made it almost impossible to challenge. To make sense of this, one of the presuppositions was that public agencies located in Stockholm should be considered as being in their'rightful location', and that this location was a prerequisite for them being able to reach their full potential. This applied not only to each organisation individually, but, in the hegemonising strategy outlined here, also to the nation, and the nation's potential, by not incurring an unnecessary loss of competence.

\section{Countering the discourse about competence}

The stance that dominated the discourse about competence primarily claimed that it was morally wrong to 'throw out' the competence that had long been cultivated in Stockholm by moving government agencies elsewhere. This was countered primarily by the argument that it was unfair to believe that no competence existed outside Stockholm. Reactions to the notion that competence was only to be found in Stockholm were represented as stirring emotion. In the quotes below this comes forth explicitly as in the references to 'sick' and 'furious', and more implicitly as in the last quote.

It makes you sick to hear in the media that all the expertise is found only in Stockholm. What makes them think that? (Letter to the editor, 2005)

Tuesday's broadcast of the radio programme P1 Morning, Värmland's County Governor Eva Eriksson was furious that the debate seems to assume that the level of competence in Värmland is lower than in Stockholm. (Kjöller, 2005)

What gives frustrated Stockholmers the right to single out Karlstad/Kristinehamn as so unattractive that no one wants to move there? Why don't they think we can attract skilled labour when needed? (Fredriksson, 2005)

In the last quote, it is in fact the 'Stockholmers' that are connected with feelings of frustration, rather than the ones being portrayed as incompetent by the discourse. Eriksson (2010a) describes how hegemonic representations of competence and incompetence in 
relation to place conceal heterogeneity both within and outside the big cities. This kind of one-sided representation, Eriksson claims, provokes 'the othered ones' to take a defensive position. One strategy found in our material that came from such a defensive positioning was to use 'Stockholmers' as a pejorative, and to take an ironic, even sarcastic, stance towards what on a general level seemed to be the dominant discourse. The quote about frustrated Stockholmers should be read with this in mind. It is an example of a counterdiscourse where the criticised discourse about competence is thwarted by arguing that its proponents are frustrated and emotional as opposed to rational and reasoned. Similarly, the public agencies located in the capital were depicted as whiny, spoiled and self-centred.

Without fail the wail goes up when a handful of state agencies and a couple of thousand jobs are to be relocated from the capital. The main argument is the loss of competence within the agency because so few employees will want to move with it. [...] I don't give a Fig. for the argument about loss of competence. (Lundgren, 2005)

One example is the National Electrical Safety Board, which seems to believe that electrical skills do not exist outside Stockholm. (Wassenius, 2005)

This way of relating sarcastically to 'the centre' has a very long history in Sweden (Hansen, 1998; Nilsson, 2009) and has been expressed in public debate as well as in popular culture (Eriksson, 2010a). Although forming an established counter-discourse, it simultaneously indicates the uneven power relations that make it possible. Davidson and Bondi (2004, p. 373) state that emotions are'phenomena that partially shape, and are shaped, by our interactions with the people, places and politics'. Countering the discourse of competence shows how geographical spaces became stereotypically associated with different emotional states (cf. Hopkins, 1998). There was no question that these associations with emotional characteristics were related to the distribution of power, and constitutive of notions of place-related identities. Together with the emotionally invested defence against accusations of incompetence, they revealed how '[e]motions are an intensely political issue' (Anderson \& Smith, 2001, p. 7).

\section{Concluding discussion: the emotional and moral geographies of relocation fantasies}

We have given examples of what emotions and morality did in the news press discourses on public sector job relocation. One conclusion is that in many cases, morality and emotionality seemed to have made it possible to keep the arguments 'empty': in other words, moral values and emotions were used as a kind of ultimate truth that did not require additional justifications, and so could be accepted by different protagonists. Ahmed (2004) argues that this could be a function of emotions for political purposes that sustain relations of domination and subordination. While acknowledging that the uses of morality and emotion have universalising claims, we would also argue, in accordance with the research field of emotional geography, that they must be viewed as both geographically situated and situating. Rather than just acknowledging the way different places may harbour different emotions and morals, expressing notions of emotions and morals is also performative and constitutive of places and the people that are associated with them. In this way, the emotional arguments that highlighted the moral right to relocate government agencies (advocated primarily by the news press located in the 'regions') contributed to constructing these regions as at once 
deserving and dependent, thus always in a subordinate position to the centre of Stockholm. Similarly, the indignant and emotional critique of the relocations inherent in the discourse about competence (and mainly represented by news press located in the Stockholm area) worked to naturalise Stockholm as the evident competence node. Even when this naturalisation was questioned (by voices that were mostly positioned outside Stockholm), the strong and emotionally charged arguments narrated a long history of being devalued and unrecognised by the centre. Overall, geographical position was more decisive than the newspapers' political affiliation.

The uses of morality and emotion to justify arguments in the debates thus open up for an analysis of how geography is continuously constituted, but also of the fantasmatic investments that work as driving forces in this ongoing pursuit. In the case studied here, it seemed clear that the fantasmatic investments in the different discourses of relocation worked as driving forces in the debates, but that fantasmatic investments also worked to connect the issues of relocation of state agencies with spatial identities. That these identities were unequally positioned became clear as their emotional expressions were analysed. Most of the studied news press articles expressed indignation, frustration and anger, but while texts written from the 'regions' did so from a subordinate position, the texts written from the Stockholm area took its right to the agencies more for granted.

One can say that the discourse about compensation was structured by an ideological fantasy of a strong responsible state, and that this fantasy fuelled the demands for righteous compensation. The fantasy was accompanied by notions of past neglect, in which the receiving areas were represented as doubly deserving. This fantasy was primarily articulated as situated outside Stockholm - in the regions in question for relocation - and it was both emotionally and morally charged. It was in relation to this fantasy that the discourse about compensation could be vindicated with such dedication. Although positioning its subjects as subordinate and perhaps even incapacitated, it simultaneously offered a position as 'deserving', which constituted a strong argument in the relocation debate.

The discourse about competence seemed to be driven by a fantasy in which relocation decisions should be left to market forces. Since it came with the notion that there is a shortage of competence outside Stockholm, and that people are bound to place and reluctant to move, arguments invested in this fantasy were represented as appalled by suggestions of relocation, primarily since it argued that the supposed organisational brain-drain and increased costs would seriously undermine the efficiency of the relocated agencies. This was comprehended as immoral, not primarily in relation to people or areas, but in relation to the agencies' efficiency and tax payers' money. This fantasy of the market as the ultimate regulator, and of competence as residing only in Stockholm, offered employees in Stockholm the chance to feel and identify as especially competent. What however seemed to be specifically enjoyable and thus often put forth in the represented debate was the potential of the fantasy to offer Stockholmers the possibility to present themselves as having their competence unacknowledged. Being positioned as deserving put them in a justifiable position to make certain claims, although, again, these claims were more often raised in the name of the agencies or the nation rather than in the name of the employees.

The counter-discourse critiquing the discourse about competence called the content of the discourse into question, thus destabilising the notions of who was competent and who was not. However, the manner in which this was done made it clear that the criticised 
representations of competence were not only 'wrong' and morally 'unfair' - they were also heavily invested in already-established geographic power relations. In this sense, the counter-discourse helped to show how the neoliberal fantasy that informed the discourse about competence was not as objectively calculating as it claimed to be. The representations of the affected counter-discourse revealed that the discourse about competence was not only blind to the different conditions of geographic areas, but also to how it was itself involved in shaping these conditions.

According to Žižek (1989), fantasies explain why ideals never become fully realised, why fulfilment is missing. The fantasy of the responsible state could explain the critical situation by ascribing to it an inability to act. If only the state came to its senses and decided on relocation, everything would be fine, was the logic of this fantasy. Similarly, the fantasy of market forces and the concentration of competence in Stockholm could well explain that the critical situation was due to the 'irrational' choice to move central agencies to places with no competence. The logic of this fantasy was that if only market forces were to decide, everything would be fine. In both cases, the fantasies offer promises of solutions, but also explanations to why these promises have not yet been fulfilled (Dean, 2007; Glynos \& Howarth, 2007). Accusing the Other of such theft of enjoyment effectively conceals 'the traumatic fact that we never possessed what was allegedly stolen from us' (Žižek, 1993, pp. 203, 204). Suggesting such a theft of enjoyment - as both the news press discourses did - stabilises (spatial) borders between (the deprived but morally righteous) us and the (stealing and morally undeserved) Other. It should however be highlighted that 'the rational mode' also needs to be seen as affective (Sjöstedt Landén, 2011).

Both discourses relied on what could be called a logic of centre and periphery (Sjöstedt Landén, 2012a). Cresswell (2005, p. 129) has pointed out that any notion of moral geography not only begets moral citizens, it also 'has to touch on theoretical or immoral geographies' and citizens. The conviction to be 'right' clearly legitimised much of the argumentation and also had to do with emotionally invested fantasies of (political) space. Beatific fantasies of Sweden's regions surviving if only the loss of jobs were compensated for surfaced in arguments in favour of public sector relocation. At the same time, loss of competence - ultimately affecting the nation - was prominent in the arguments against relocations. In both discourses, there was little room for articulating and analysing how the performance of peripheral areas 'depends not only on their "internal" structural characteristics but also on their articulation with the rest of the European economy and with the international market' (Hadjimichalis, 2003, p. 111). A perspective of fantasy contributes to an analysis that highlights that the relocations of public sector agencies brought out and became a symbol for what different areas were in the eyes of the Other (cf. Dean, 2007). The debate about relocating state agencies or keeping them in Stockholm thus becomes a symbol for how the keeping and receiving areas are valued on a national level. The tensions between a discourse about compensation and a discourse about competence are telling of the power dynamics built into the articulations of public sector job relocation in public debate.

\section{Notes}

1. Sweden has three major urban regions that are concentrated to the southern part of the country; Göteborg, Malmö and Stockholm. Stockholm is the Capital city. Two million people live in the Stockholm region and the whole country has a population of approximately 9 million. 
2. The discourse about compensation was not only articulated in relation to the relocation of government agencies. It also drew on existing claims for compensating the internal colonisation of natural resources that has marked the conditions for much of the population on the Swedish countryside and had severe effects on indigenous culture and living conditions during the twentieth century (Sörlin, 1988). From the second half of the twentieth century, urbanisation was extensive and fast in Sweden and streams of migration went from the countryside to the major cities and especially Stockholm (Borgergård, Håkansson, \& Malmberg, 1995). The people living in a region provide the tax base for the local governments which means that the bigger cities have had a great growth while many of the so-called regions - especially in the north of Sweden - have been under pressure with out-migration and deprived labour markets.

3. This is a way of arguing about competence and qualified workforce that is also embedded in (neo)liberal discourse of globalisation where'policies to counteract the population drift away from the country's sparsely populated areas' - such as public sector job relocations - could be seen as 'counterproductive' when the large cities will be of 'highest importance' in the global market economy (see Sjöstedt Landén, 2012a, p. 61 quoting Andersson \& Thulin, 2008).

\section{Disclosure statement}

No potential conflict of interest was reported by the authors.

\section{Funding}

This work was supported by the Svenska Forskningsrådet Formas [grant number 2007-2079].

\section{References}

af Kleen, B. (2005, January 27). Utgrävningschefer fruktar flytt till Visby [Managers of archeological diggings fear move to Visby]. Sydsvenskan, p. 2.

Ahmed, S. (2004). The cultural politics of emotion. Edinburgh: Edinburgh University Press.

Anderson, K., \& Smith, S. J. (2001). Editorial: Emotional geographies. Transactions of the Institute of British Geographers, 26, 7-10.

Andersson, B. (2005, January 22). Hälften av jobblöftena till försvarsorter sveks [Half of the jobs promised for defence towns let down]. Dagens Nyheter, p. 2.

Berger, S. (1995). Regionala olikheter och regionalpolitik [Regional differences and regional politics]. In S. Berger (Ed.), Samhällets geografi [The geographies of society] (pp. 171-192). Stockholm: Nordisk samhällsgeografisk tidskrift.

Berlant, L. (2000). The subject of true feeling: Pain, privacy and politics. In S. Ahmed, J. Kilby, C. Lury, M. McNeil, \& B. Skeggs (Eds.), Transformations: Thinking through feminism (pp. 33-47). London: Routledge.

Bjurnemark, U. (2005, January 26). Signerat: Flytta utan nytta [Signed: Move without use]. Sydsvenskan, p. 4.

Boltanski, L., \& Thévenot, L. (1999). The sociology of critical capacity. European Journal of Social Theory, 2, 359-377.

Boltanski, L., \& Thèvenot, L. (2006). On justification: Economies of worth. Princeton, NJ: Princeton University Press.

Borgergård, L.-E., Håkansson, J., \& Malmberg, G. (1995). Population redistribution in Sweden: Long term trends and contemporary tendencies. Geografiska Annaler. Series B, Human Geography, 77, 31-45.

Brandt, D. (2010). Geografiska perspektiv på den moderna statens organisering [Geographical perspectives on the organization of the modern state]. Örebro Studies in Human Geography 5. Örebro: Örebro Universitet.

Brors, H. (2005, March 7). Experterna styrs med korta tömmar [Experts are governed with short reins]. Dagens Nyheter, p. 23. 
Brown, G., \& Pickerill, J. (2009). Space for emotion in the spaces of activism. Emotion, Space and Society, 2, 24-35.

Carlsson, U. (2014). Nordicom- Sveriges Mediebarometer 2014. Standard Eurobarometer 82. Göteborg: Nordicom Sverige. Retrieved from http://ec.europa.eu/public_opinion/index_en.htm

Cresswell, T. (2005). Moral geographies. In D. Atkinson (Ed.), Cultural geography: A critical dictionary of key ideas (pp. 128-134). London: I. B. Tauris.

Curti, G. H., Aitken, S. C., Bosco, F. J., \& Dixon Goerisch, D. (2011). For not limiting emotional and affectual geographies: A collective critique of Steve Pile's 'emotions and affect in recent human geography'. Transactions, 36, 590-594.

Davidson, J., \& Bondi, C. (2004). Spatialising affect; affecting space: An introduction. Gender, Place \& Culture: A Journal of Feminist Geography, 11, 373-374.

Davidson, J., Bondi, L., \& Smith, M. (2007). Emotional geographies. Hampshire: Ashgate.

Davis, S., Crothers, N., Grant, J., Young, S., \& Smith, K. (2012). Being involved in the country: Productive ageing in different types of rural communities. Journal of Rural Studies, 28, 338-346.

Dawney, L. (2011). The motor of being: A response to Steve Pile's 'emotions and affect in recent human geography'. Transactions, 36, 599-602.

Dean, J. (2007). Why Žižek for political theory? International Journal of Žižek Studies, 1, 18-32.

Eriksson, M. (2008). (RE)producing a "peripheral" region - Northern Sweden in the news. Geografiska Annaler: Series B, Human Geography, 90, 369-388.

Eriksson, M. (2010a). "People in Stockholm are smarter than countryside folks" - Reproducing urban and rural imaginaries in film and life. Journal of Rural Studies, 26, 95-104.

Eriksson, M. (2010b). Reproducing a periphery. Popular representations of the Swedish North. Umeå: Department for Social and Economic Geography, Umeå University.

Foucault, M. (1980). Power and strategies. In C. Gordon (Ed.), Power/knowledge: Selected interviews and other writings 1972-1977 by Michel Foucault (pp. 134-145). Brighton: Harvester.

Fraser, N. (2009). Social justice in the age of identity politics. Redistribution, recognition, and participation. In L. Ray \& A. Sayer (Eds.), Culture and economy after the cultural turn (pp. 25-52). Thousand Oaks, CA: Sage.

Fredriksson, J. (2005, March 1). Bra rutet [A good rant]. Göteborgs Tidningar, p. 2.

Glynos, J. (2001). The grip of ideology: A Lacanian approach to the theory of ideology. Journal of Political Ideologies, 6, 191-214.

Glynos, J. (2008). Ideological fantasy at work. Journal of Political Ideologies, 13, 275-296.

Glynos, J. (2009). Body, discourse and the turn to matter. In S. Bahuh \& D. Radunovic (Eds.), Language, ideology, and the human (pp. 173-192). London: Ashgate.

Glynos, J., \& Howarth, D. (2007). Logics of critical explanation in social and political theory. Abingdon: Routledge.

Hadjimichalis, C. (2003). Imagining rurality in the new Europe and dilemmas for spatial policy. European Planning Studies, 11, 103-113.

Halfacree, K. (1993). Locality and social representation: Space, discourse and alternative definitions of the rural. Journal of Rural Studies, 9, 23-37.

Halfacree, K. (2006). Rural space: Constructing a threefold architecture. In P. Cloke, T. Marsden, \& P. Mooney (Eds.), The handbook of rural studies (pp. 44-62). London: Sage.

Hansen, K. (1998). Välfärdens motsträviga utkant: Lokal praktik och statlig styrning i efterkrigstidens nordsvenska inland [The unruly outskirts of welfare: Local practice and state governance in the northern Swedish inland after the second World War]. Lund: Historiska Media.

Hall, S. (1997). The work of representation. In: S. Hall (Ed), Representation. Cultural representations and signifying practices. London: Sage Publications.

Harvey, D. (1996). Justice, nature and the geography of difference. Oxford: Balckwell.

Hennel, L. (2004, September 25). Fängelser ersätter regementen [Prisons replace regiments]. Svenska Dagbladet, p. 12.

Hopkins, J. (1998). Signs of the post-rural: Marketing myths of a symbolic countryside. Geografiska Annaler, Series B: Human Geography, 80, 65-81.

Horton, J., \& Kraftl, P. (2009). What (else) matters? Policy contexts, emotional geographies. Environment and Planning A, 41, 2984-3002. 
Howarth, D. (2000). Discourse. Buckingham: Open University Press.

Hudson, C., \& Rönnblom, M. (2007). Regional development policies and the constructions of gender equality: The Swedish case. European Journal of Political Research, 46, 47-68.

Isaksson, G.-E. (1989). Resultatlös omlokalisering [Relocation without result]. Åbo: Åbo Academy Press. Jansson, D. R. (2003). Internal orientalism in America:W. J. Cash's 'The Mind of the South' and the spatial construction of American national identity. Political Geography, 22, 293-316.

Jarosz, L. \& Lawson, V. (2002). Sophisticated people versus rednecks': Economic restructuring and class difference in America's West. Antipode, 34(1), 8-27.

Kihlström, S. (2004, December 2). Få jobb på statliga verk kan flyttas ut i landet [Few state government jobs can be moved out to the country]. Dagens Nyheter, p. 12.

Kjöller, H. (2005, March 2). Hanne Kjöller: kompetens här och där [Hanne Kjöller: Competence here and there]. Dagens Nyheter, p. 4.

Krantz, M. (2008 September 30). Stockholm är inte räddningen [Stockholm is not salvation]. Gotlands Tidningar, p. 11.

Laclau, E. (1993). Power and representation. In M. Poster (Ed.), Politics, theory and contemporary culture (pp. 277-296). New York, NY: Columbia University Press.

Laclau, E. (2005). On populist reason. London: Verso.

Laclau, E., \& Mouffe, C. (1985). Hegemony and socialist strategy. London: Verso.

Larsson, H. (2005, January 31). Omlokalisering stärker Sverige [Relocation strenthens Sweden]. Östersunds Posten, p. 9.

Lee, C. S., \& Ma, L. (2012). News sharing in social media: The effect of gratifications and prior experience. Computers in Human Behavior, 28, 331-339.

Lee, R., \& Smith, D. M. (2004). Geographies and moralities. Malden, MA: Blackwell.

Lefebvre, H. (2003). Space and the state. In N. Brenner, B. Jessop, M. Jones, \& G. MacLeod (Eds.), State/ space (pp. 84-100). Berlin: Blackwell.

Letter to the editor. (2005, January 27). Expressen.

Ljuslinder, K. (2002). Pånära håll är ingen normal. Handikappdiskurser i Sveriges television 1956-2000 [At a closer look no one is normal: discourses about disability in Swedish television 1056-2000]. Umeå: Umeå University, Department of Culture and Media.

Linder, M. (2009, December 29). Flyttkarusell sätter snurr på stålarna [Moving carousel spins dough]. Gotlands Allehanda, p. 2.

Lundgren, E. (2005, April 12). Sluta gnäll [Stop whining]. Östersunds Posten, p. 2.

Lundgren, A. S. (2011). Ageing in the Norrlandic inland. In A. Egan Sjölander \& J. Gunnarsson Payne (Eds.), Tracking discourses. Politics, identity and social change (pp. 313-338). Lund: Nordic Academic Press.

Marshall, J. N. (2007). Public sector relocation policies in the UK and Ireland. European Planning Studies, $15,645-666$.

Marshall, J N., Hodgson, C., \& Bradley, D. (2005). Public sector relocation and regional disparities in Britain. Environment and Planning C: Government and Policy, 23, 883-906.

Massey, D. (2005). For space. London: Sage.

Mindre värda myndigheter [Less worthy goverment agencies] (2005, January 26). Dagens Industri.

Nilsson, B. (2009). Kiruna: staden som ideologi [Kiruna: The town as ideology]. Umeå: Boréa.

Persson, M.-Å. (2004, September 22). -Se vad som hände i Kiruna och Sollefteå [-Look what happened in Kiruna and Sollefteå]. Ola Sundell varnar för lovade ersättningsjobb. Östersunds Posten, p. 5.

Pile, S. (2010). Emotions and affect in recent human geography. Transactions, 35, 5-20.

Pred, A. (2000). Even in Sweden: Racism, racialized spaces and the popular geographical imagination. Berkeley: University of California Press.

Pripp, T. (2004, October9). Tacka nej till ett fängelse i länet [Decline the offer of localizing a prison in the region]. Östersunds Posten, p. 9.

Rädda svensk kulturvård [Save the care for Swedish culture]. (2007, September 22). Enköpings Posten. Riksrevisionen. (2009). Omlokalisering av myndigheter [Relocation of government agnecies]. RiR 2009:30. Stockholm: Riksrevisionen.

Sjöstedt Landén, A. (2011). Exploring ideological fantasies on the move. In A. Egan Sjölander \& J. Gunnarsson Payne(Eds). Tracking discourses: Politics, identity and social change (pp. 287-312). Lund: Nordic Academic Press. 
Sjöstedt Landén, A. (2012a). Moved by relocation, professional identification in the decentralization of public sector jobs in Sweden. Umeå: Department for Culture and Media Studies, Umeå University.

Sjöstedt Landén, A. (2012b). Moving central knowledge to a northern periphery: Exploring logics of public-sector job relocation in Sweden. Geografiska Annaler: Series B, Human Geography, 94, 333-350.

Sörlin, S. (1988). Framtidslandet: debatten om Norrland och naturresurserna under det industriella genombrottet [The land of the future: The debate about Norrland and the natural resources under the industrial revolution]. Stockholm: Carlssons.

Statskontoret. (1989). Omlokalisering av statliga myndigheter, utvärdering av utflyttningen på 70-talet [Relocation of government agencies, evaluation of the moves in the 70s]. 1989:8A. Göteborg: Graph.

Statligt mord på kompetens [Sate murder on competence]. (2005, December 12). Dagens Industri.

Terdiman, R. (1985). Discourse/counter-discourse: The theory and practice of symbolic resistance in nineteenth-century France. Ithaca, NY: Cornell University Press.

Torfing, J. (1999). New theories of discourse: Laclau, Mouffe and Zizek. Oxford: Blackwell.

Trondal, J. (2011). Geografi og Byråkrati [Geography and bureaucracy]. Oslo: Universitetsforlaget.

Valentine, G. (2013). Producing moral geographies: The dynamics of homophobia within a transnational religious network. The Geographical Journal, 179, 165-176.

Vallström, M. (2014). När verkligheten inte stämmer med kartan: Lokala förutsättningar för hållbar utveckling [When reality does not match the map: local conditions for sustainable development]. Lund: Nordic Academic Press.

Verken vill inte flytta till länet [The government agencies does not want to move to the region]. (2004, December 21). Östersunds Posten.

Verkschef vill inte lämna Stockholm [General director won't leave Stockhom]. (2004, September 25). Dagens Nyheter.

Vilka är de viktigaste statliga åtgärderna som måste vidtas om garnisonen läggs ned [What are the most important government measures if the garrison is closed down]. (2004 September 21). Östersunds Posten.

Wahl-Jorgensen, K. (2013). The strategic ritual of emotionality: A case study of Pulitzer Prize-winning articles. Journalism, 14, 129-145.

Wassenius, G. (2005March 3). När fiskeristyrelsen bildades 1948 var det en sensation [It was sensational when the agency for fisheries was founded in 1948]. Nerikes Allehanda, p.35.

Winckler, V. (1990). Restructuring the civil service: Reorganization and relocation 1962-1985. International Journal of Urban and Regional Research, 14, 135-157.

Woods, M. (2006). Political articulation: The modalities of new critical politics of rural citizenship. In P. Cloke, T. Marsden, \& P. Mooney (Eds.), Handbook of rural studies (pp. 457-471). London: Sage.

Woods, M. (2011). Rural. London: Routledge.

Zimmerman, K. F. (2009). Labour mobility and the integration of European labour markets. In E. Nowotny, P. Mooslechner, \& D. Reisberger-Grünwald (Eds.), The integration of European labour markets (pp. 9-23). Cheltenham: Edward Elgar.

Žižek, S. (1989). The sublime object of ideology. London: Verso.

Žižek, S. (1993). Tarrying with the negative. Durham, NC: Duke University Press. 